\title{
A Eqüidade e o Direito do Trabalho.
}

\author{
Wagner D. Giglio \\ Professor Livre Docente de Direito do \\ Trabalho da Faculdade de Direito da \\ Universidade de São Paulo
}

\begin{abstract}
SUmário: I. Conceito: 1. Etimológico; 2. Popülar; 3. Histórico; 4. Doutrinário - II. FUnçốes No DiReITo: 1. No suprimento de lacunas: a) pela atuação do legislador; b) pela atuação do juiz; 2. Na interpretação do direito; 3 . Na aplicação do direito - III. Funções No Direito BRASIleiro: 1. Na Constituição de 1934; 2. Na Lei de Introdução ao Código Civil; 3. No Código Civil; 4. Nos Códigos de Processo Civil - IV Funções no Direito do Trabalho: 1. No suprimento de lacunas; 2 . Na atividade dos mediadores; 3 . Na Aplicação do direito - V. Funções no Direito do Trabalho Brasileiro: 1. Na Consolidação das Leis do Trabalho; 2. Na Justiça do Trabalho - VI. Conclusões.
\end{abstract}

Honrados pela indicação do eminente Professơr MigueL REALE, atuamos como seu debatedor na conferência que proferiu sobre Temas Fundamentais de Filosofia do Trabalho, no Curso Interdisciplinar de Direito do Trabalho, organizado pelo Departamento de Direito do Trabalho da Faculdade de Direito da Universidade de São Paulo, em comemoração ao sesquicentenário da fundação dos cursos jurídicos no Brasil.

Naquela oportunidade defendemos posição baseada em estudo anterior sobre o papel da eqüidade, no Direito do Trabalho. Eis a íntegra do referido estudo.

I.

Convém, de início, conceituar o termo eqüidade, como preliminar do estudo. E aqui já deparamos com o primeiro obstáculo a ser vencido, vez que não há acordo, entre os doutrinadores, sobre a compreensão exata do vocábulo.

1. As palavras "equity", "equità", "equité", "equidad" e "eqüidade" derivam, por via erudita, do latim "aequitatem"; a evolução etimológica vulgar resultou, por aglutinação do 
grupo "ae" em " $i$ ", atenuação dos sons fortes " $q$ " $e$ " $t$ " em "g" e "d", e perda do " $\mathrm{m}$ " final (também do " $\mathrm{e}$ " final, em espanhol), em "igualdade" e "igualdad".

2. Na linguagem popular, "eqüidade". retém o significado original de igualdade e, por extensão de sentido, equivale à imparcialidade, retidão, justiça, serenidade, equilíbrio, moderação.

A conotação de igualdade parece, à primeira vista, repelir a aplicação da eqüidade ao Direito do Trabalho, que nasceu da desigualdade e ainda hoje tem como principal objetivo combatê-la, compensando, na célebre fórmula de GALLART FoLCH, com a outorga de uma superioridade jurídica ao trabalhador, a situação de inferioridade econômica em que se encontra, diante do empregador. Tratá-los com eqüidade, isto é, com igualdade, seria restabelecer a injustiça dos primórdios da revolução industrial.

Isso não ocorre, contudo, porque a expressão "igualdade", do ponto de vista jurídico, perdeu, modernamente, o sentido original, eivado de individualismo liberal. Hoje, o "todos são iguais perante a lei" sé entendido como tratamento desigual dos que estão em situações ou relações diferentes, e igual apenas daqueles que se encontram em posições semelhantes.

3. A noção original de eqüidade, entretanto, provém de ARISTóteles, na Ética a Nicômaco: "O equitativo, sendo superior a uma espécie do justo, é justo, e não é superior ao justo, porque pertence a um gênero diferente. $O$ justo e o equitativo são, pois, uma só e a mesma coisa; ambos são bons mas o equitativo é bom a um grau mais alto. O que faz a aporia, é que o equitativo, mesmo sendo justo, não é o justo segundo a lei, mas uma correção do justo legal" (apud EDUARDo Spínola FILHo, in Repertório Enciclopédico do Direito Brasileiro, v. XX, p. 244).

Elaborando sobre a idéia, algo obscura, estendeu-se o filósofo em comentários que apresentam interesse: "O equitativo parece ser o justo, mas é o justo que ultrapassa a lei escrita. As lacunas desta são, umas queridas pelos legisladores, as outras involuntárias" (...) "Vê-se claramente que espécie de atos devem ser apreciados segundo a eqüidade, que atos não o devem" (...) "Ser equitativo é ser indulgente com as fraquezas humanas; é considerar não a lei, mas o legislador; não a letra da lei, mas o espírito daquele que a fez; não a ação, mas a intenção; não a parte, mas o todo; não o que é atualmente o acusado, mas o que ele foi sempre, ou a maior 
parte do tempo" (...) "É consentir que uma contenda seja resolvida antes pela palavra do que pela ação, preferir submeter-se a um arbitramento em vez de um julgamento pelos tribunais, porque o árbitro vê a eqüidade, o juiz não vê senão a lei; o árbitro não foi, aliás, inventado senão para dar força à eqüidade" (op. e loc. cit.).

Nota-se a preocupação do preceptor de Alexandre em equacionar as relações entre o Direito e a Justiça, entre o legal e o ético, colocando a eqüidade no plano ideal de uma justiça intuitiva, natural e humana, superior e mais perfeita do que a da norma jurídica. A eqüidade corresponderia ao justo aperfeiçoado, à Justiça ideal, e sua missão seria suprir as omissões da lei e orientar o intérprete na correção das injustiças.

A atividade do pretor romano emprestou sentido prático à noção aristotélica de eqüidade, ao corrigir a lei e criar direito novo para a solução dos casos concretos, abandonando os textos legais em busca do ideal de justiça.

O tema foi retomado por outros filósofos, entre eles BACoN (in De Certitudine Legum), HoBBEs in De Cive, LEIBNITZ, (in Observaciones de Principiis Juris), e KANT (in Metaphysische Anfangsgründe der Rechtslehre), cujas idéias deixamos de analisar face às naturais limitações deste trabalho.

Cumpre lembrar, entretanto, que os estudos sobre eqüidade retomaram grande impulso nos últimos anos do século passado e primeiros, do atual, durante o fastígio da escola do direito livre. Não obstante a elaboração processada no correr dos séculos, uma das maiores expressões dessa escola de interpretação, FrANÇoIs GENY, confessava candidamente que a noção de eqüidade ainda permanecia "algo incerta e equívoca, que não parece, em nada, se distinguir, muito nitidamente, da noção de justiça" (apud SPínOla FilHo, op. cit., p. 246).

4. Na doutrina moderna, a eqüidade é tida como "princípio geral do Direito, o mais geral de todos" (...), "ponte por excelência entre a Justiça e a Lei" (. . . ) e "fonte de standards juridicos" por JOSÉ MARTINS CATHARINO ( in Compêndio Universitário de Direito do Trabalho, v. I, p. 117) ; como "a justiça do juiz, em contraposição à lei, justiça do legislador" por CARNELUTTI, citado por DÉLIo MARANHÃo (in Instituições de Direito do Trabalho, $4 .^{\text {a }}$ ed., v. I, p. 185) ; como "la justicia natural, manifestada por la conciencia jurídica del pueblo" por LUIGI De LiTAla (in Derecho Procesal del Trabajo, v. I, p. 76) ; como "a idéia do justo" que "abranda o rigor do texto" 
e "aquece a frieza da lei" por Mozart V. Russomano (in Comentário à $C L T, 3{ }^{a}$ ed., v. I, p. 80) ; como "la justicia del caso concreto" que "sirve para corrigir a la justicia", adaptando-a, não sendo “ um princípio ni una fórmula general derivada de la idea de justicia, sino un procedimiento y un resultado: Es la armonia entre lo general y lo particular" por MARIO DE LA CUEVA (in Derecho Mexicano del Trabajo, 4. ${ }^{\text {a }}$ ed., v. I, p. 395) ; e como correspondente "ao sentimento de justiça que deve influenciar o legislador na elaboração da lei e - juiz na sua interpretação" por ARNALdo LOPES SUSSEKIND (in Comentários à CLT $e$ à Legislação Complementar, V I, p. 208).

Os conceitos atuais variam, como se vê, de acordo com a posição de cada autor face ao problema das funções da eqüidade no Direito.

II.

$\mathrm{Na}$ visão mais ampla possível, a atuação do Direito no mundo contemporâneo pode ser classificada em dois tipos: o do "common law" e o dos sistemas derivados do direito romano. Características daquele são a grande liberdade dada ao juiz na pesquisa e aplicação do Direito, e o papel preponderante dos precedentes judiciários. Nos sistemas de extração romana, há acentuado predomínio da norma jurídica escrita, restringindo a liberdade do aplicador do Direito.

Interessa-nos examinar as funções da eqüidade nos sistemas do segundo tipo, prevalente no mundo latino.

1. As normas jurídicas escritas, entretanto, não esgotam o Direito, mesmo porque seria impossível que o legislador previsse todas as hipóteses da vida real, regulando-as por antecipação. A vida moderna, em rápida evolução, cria situações novas, modifica relações antigas, altera condições sociais e substitui valores.

a) As novas formas de comportamento social devem ser reguladas pelo Direito, de preferência através de legislação atualizada. Assim, cabe primordialmente ao legislador encontrar novas fórmulas legais, novos moldes jurídicos para as relações sociais emergentes.

Nessa tarefa a eqüidade - entendida no sentido original, mais amplo, de justiça - funciona como ideal a ser atingido pelo legislador, pois não se concebe, logicamente, a existência de direito iníqüo, injusto. A norma jurídica escrita que, por 
distorção, revelar-se injusta, não representa o direito, e merece derrogada.

A eqüidade, nessa função, constitui portanto um postulado de Justiça: o princípio axiomático de que o Direito tende a alcançar o ideal de Justiça.

A vastidão desse conceito não permite limitações desfiguradoras. Por isso, não cremos seja viável classificar a eqüidade como fonte material de direito.

b) $\mathrm{O}$ processo legislativo é lento, e enquanto subsistem as lacunas o juiz não poderia se eximir de dar solução às controvérsias sob excusa de imprevisão legal. É forçoso, para a sobrevivência da sociedade, que o julgador resolva os litígios: Se falta a lei escrita, deve se valer de outras formas de manifestação do direito para solucionar as pendências.

$\mathrm{Na}$ terminologia corrente, havendo lacuna da lei deve o juiz buscar outras fontes de direito, tais como o contrato, os usos e costumes, os princípios gerais de direito etc.

Cogita-se, portanto, de indagar se a eqüidade se inclui entre as fontes formais de direito, muito embora entendamos, seguindo o magistério de JosÉ Martins Catharino, que se trata, a rigor, de integração do direito (cf. op. cit., p. 114).

CotRIM NETo assume posição radical: A eqüidade representa o mesmo poder "que tinha o pretor romano, de legisferar virtualmente nos casos concretos" (. . ) e até de julgar "contra legem, em determinadas circunstâncias" (apud AMAURY MASCARo NASCIMENTo, in Fundamentos do Direito do Trabalho, p. 225).

A generalidade dos autores reconhece que a eqüidade, além de auxiliar na interpretação das normas legais, "servirá también para llenar las lagunas de las otras fuentes" (DE LA CUEva, op. cit., p. 396).

DÉLIo Maranhão, porém, entende que o direito progrediu, e "muitas das soluções ditadas, antes, pela eqüidade, foram absorvidas pelo próprio direito e passaram a ser legais. Daí porque aquela função histórica da eqüidade perdeu sua importância no direito atual" (op. cit., p. 186). Peremptória, afirma SPÍNolA F..$^{\circ}$ que "a eqüidade não é, absolutamente, fonte de direito" (op. cit., p. 245), baseado em GENY, para quem a eqüidade, na função ora examinada, seria "uma espécie de instinto, 
que, sem invocação à razão raciocinante dirige, diretamente e por si mesma, à solução melhor e mais conforme com o fim de toda organização jurídica" (idem, p. 246).

Para nós, o instinto do julgador - subjetivo, intuitivo, vago e impreciso - não poderia, obviamente, ser fonte de direito, nem mesmo fonte material, como vimos, por lhe faltar caráter científico.

Compreende-se perfeitamente que, na antigüidade clássica, diante da falta de elaboração científica, fosse atribuída à noção de justiça (leia-se: eqüidade) do julgador a função de preencher os vazios da legislação. Na sociedade moderna, não. A estabilidade das relações sociais não sobreviveria a esse amplo arbítrio do juiz, pois o instinto de cada um é variável, e a intuição do justo é critério inaceitável, pela sua subjetividade e indeterminação.

Os imperativos de estabilidade e segurança das relações sociais exigem a coibição do arbítrio do julgador, e daí preverem os sistemas jurídicos contemporâneos critérios menos elásticos para suprimento de lacunas da lei escrita: usos e costumes, analogia, direito comparado, jurisprudência, doutrina e princípios gerais de direito.

As regras de procedimento do juiz, previstas pela própria lei para suprimento de lacunas, integram o direito processual, e portanto constituem normas imperativas, inderrogáveis. Esta é, aliás, a lição de DE LITALA: "Las normas procesales son normas de derecho público" (...) "y no están, por consiguiente, sujetas a interpretación equitativa" (op. cit., p. 71).

Cabe ao juiz, portanto, suprir as lacunas da lei e do contrato a poder de pesquisas sobre os usos e costumes, a jurisprudência, o direito comparado etc., para se habilitar a decidir com eqüidade, porque é seu dever precípuo ser justo, mas de acordo com os princípios gerais de direito, a analogia, a doutrina etc.

Tem razão De Page, em quem se apoia Délio Maranhão: "Não se deve refazer o direito sob pretexto de eqüidade. Esta, infelizmente, a tendência demasiado freqüente de certos juristas que, na verdade, ignoram o direito e pretendem remediar essa ignorância recorrendo à eqüidade. ." Esta "não pode jamais constituir pretexto para sentimentalismo ou generosidade" (op. cit. p. 185/186). 
Em conclusão, não é livre o juiz para julgar por eqüidade, que não é fonte formal de direito, via de conseqüência.

2. As normas jurídicas constituem preceitos genéricos de conduta em sociedade; não prevêem casos específicos e concretos, mas hipóteses gerais e abstratas. A tarefa precípua do julgador consiste em fazer a subsunção dos fatos reais às normas jurídicas, ou seja, enquadrá-los nos esquemas genéricos da legislação. Para consegui-lo, não basta inteirar-se dos fatos e conhecer o direito; é necessário interpretá-lo, isto é, desvendar o sentido das normas legais para eleger aquela que melhor se adapte à situação concreta a ser regulada.

A rigor, portanto, a missão do julgador compreende três etapas: assenhorear-se dos fatos, interpretar as normas jurídicas e aplicar o direito. A primeira é cumprida através da colheita e análise da prova; a segunda, pela utilização de métodos e técnicas; e a terceira, conclusiva, pela escolha da norma que melhor regule a situação concreta.

A interpretação das normas é uma das mais árduas tarefas do jurista, e tem sido objeto de vastíssima elaboração. No correr dos tempos, sucederam-se as escolas (histórica, da livre pesquisa, exegética etc.) e aprimoraram-se métodos e técnicas.

A evolução dos estudos levou à inserção de regras de interpretação nos sistemas jurídicos, constrangendo a atividade do julgador. Este deve se ater aos preceitos legais reguladores da interpretação, o que não significa, contudo, que a obrigação de decidir "secundum legem" exclua o critério de eqüidade, porque não se deve esquecer "que la equidad es la aspiración del espíritu universal y como tal una cualidad del derecho, no concibiéndose derecho que no sea equitativo" (...) e "si la equidad no es norma, es espíritu animador de la norma a que el intérprete debe siempre atenerse, pero sin violar el tenor de la norma misma", nas palavras de DE LitALA (op. cit., p. 76).

A eqüidade não é um método nem uma técnica de interpretação, mas um pressuposto lógico da atividade interpretativa: Se a finalidade do Direito é a Justiça, toda interpretação de suas normas deve respeitar esse fundamento teleológico, isto é, ser equitativa, tender para o justo.

Assim, voltamos a insistir, não é livre .o julgador para, fazendo abstração de métodos e técnicas, descumprindo preceitos legais que os impõem, interpretar normas jurídicas por 
eqüidade, baseado exclusivamente em sua noção intuitiva $\mathrm{e}$ subjetiva do que seja justo; deve, isto sim, pautar sua pesquisa naqueles métodos e técnicas para apreender, dentro da mais rigorosa lógica jurídica, a finalidade do preceito legal, a sua razão de ser precípua, o seu objetivo último, ou seja, interpretá- lo a partir do pressuposto fundamental de que toda a norma jurídica tende à justa composição das relações sociais. A isto chamamos, por amor à síntese, interpretar com eqüidade.

Se, porventura, a correta interpretação da norma acarretar solução iníqüa para o caso concreto, levando ao impasse do "summum jus, summa injuria", de duas, uma: ou a norma é intrinsicamente injusta, e deve ser revogada; ou foi mal adaptada aos fatos, e outro é o preceito legal que melhor os regula. Nesta última hipótese, houve erro na aplicação do direito, como examinaremos a seguir; na primeira, o defeito é da lei, mas nem por isso será possível deixar de aplicá-la, pois a estabilidade social depende, no mundo contemporâneo, do cumprimento das leis. Se ficasse ao arbítrio do juiz deixar de aplicar lei por considerá-la injusta, subverter-se-ia toda a estrutura jurídica do mundo moderno, e o caos daí resultante seria um mal infinitamente maior do que a injustiça praticada em um caso concreto, por mais lamentáveis que fossem suas conseqüências.

3. Após inteirar-se dos fatos e interpretar as normas legais, deve o julgador eleger, dentre as que possam regular a espécie, aquela mais consentânea com o objetivo de justa composição das relações sociais.

E nessa etapa que a eqüidade, como noção de justiça, correspondente, no dizer de CARNELUTTI, "al sentimiento de justicia de la generalidad de los ciudadanos en el tiempo y en el lugar en que se produce la decisión" (apud DE LITALA, op cit., p. 75), deve orientar o julgador na escolha do texto legal.

Não se trata, como querem alguns doutrinadores, de adaptar a lei ao caso concreto, no sentido de considerar a eqüidade "como uma propriedade, ou qualidade, que a norma tem, de adaptar-se às circunstâncias e às exigências do caso concreto" (SPÍNOLA F. ${ }^{\circ}$ op. cit., p. 246). As conseqüências podem ser semelhantes, mas o método lógico a ser utilizado é o indutivo, e não o dedutivo, como pretendido, porque "ex facto oritur jus": São os fatos que indicam o direito aplicável. A obrigação inversa, isto é, de adaptar o direito aos fatos, é do legislador; diante do direito posto, a missão do aplicador é a de, considerando as particularidades e circunstâncias do caso con- 
creto, pesquisar e escolher o esquema legal genérico a que melhor se adaptem os fatos, utilizando-se da eqüidade como critério dessa adaptação.

E nessa fase do processo mental do julgador, muito menos estudada mas tão importante quanto a de interpretação, que a eqüidade assume importante papel, pois as cogitações intelectuais do juiz são livres: Ao contrário da atividade interpretativa, não estão reguladas por lei.

De todo o exposto podemos concluir que eqüidade significa justiça perfeita, meta ideal do legislador, na elaboração da norma jurídica, e do juiz, na aplicação do direito.

III.

Segundo R. Limongi França "há pelo menos três modos de fundamentar o exercício da Eqüidade no Direito Positivo Brasileiro: a) nos textos que expressamente referem o termo Equiidade; b) nos textos que, sem referir essa palavra, direta ou indiretamente apelam para o prudente arbitrio do magistrado; c) nos textos gerais, referentes à interpretação e aplicação da lei" (in Formas e Aplicação do Direito Positivo, p. 76).

Como vimos, nas hipóteses sub "b" e "c" a eqüidade funciona como pressuposto lógico da atividade interpretativa. Limitemo-nos por isso, ao estudo de alguns casos mais característicos de menção expressa da eqüidade, no Direito Brasileiro.

1. Ainda influenciada pela corrente mais moderada da escola da livre pesquisa do direito, representada por GENY e, entre nós, por Clovis BeviLÁQUA, dispunha o art. 113, n. ${ }^{\circ} 37$ da Constituição Brasileira de 1934, ao tratar dos direitos e das garantias individuais, que "nenhum juiz deixará de sentenciar por motivo de omissão da lei. Em tal caso, deverá decidir por analogia, pelos princípios gerais de direito ou por eqüidade."

A eqüidade era tida, naquele regime, como fonte supletiva de integração do Direito. Face à lacuna da lei, o juiz deveria se utilizar, preferencialmente, da analogia, e não conseguindo, por esse meio, encontrar a solução para o caso concreto, valer-se-ia dos princípios gerais de direito. Sendo a eqüidade o mais genérico desses princípios, a única explicação plausível da sua função seria a de, inexistindo outro princípio geral aplicável à espécie, conceder inteira e total liberdade ao juiz para julgar como lhe parecesse mais justo, fundamentando sua 
decisão naquela noção subjetiva, imprecisa e intuitiva de um ideal de Justiça.

As Constituições posteriores, de 1937 e de 1946, bem como a atual, de 1967, emendada em 1969, não reproduziram a disposição, relegando a matéria à legislação ordinária.

2. A lei de Introdução ao Código Civil, que a doutrina tem como repositório dos princípios informadores de todo o direito privado brasileiro, reza, no art. $4 .^{\circ}$ : "Quando a lei for omissa, o juiz decidirá o caso de acordo com a analogia, os costumes e os princípios gerais de direito."

Embora o Código Civil Brasileiro date de 1917, sua Lei de Introdução foi modificada em 1942. O texto transcrito, do art. $4 .^{\circ}$, revela a evolução dos estudos, ao excluir a menção à eqüidade. Ressalta SPfNola F. ${ }^{\circ}$ que a omissão foi intencional: "A vigente Lei de Introdução" (...) "deixa, positivamente, claro não ter a eqüidade na consideração de fonte do direito, pois, enumerando os elementos da integração da ordem jurídica positiva, manda se utilize o aplicador, se omissa a lei, da analogia, ou recorra às duas únicas fontes subsidiárias - o costume e os princípios gerais de direito" (op. cit., p. 248).

Para Clovis BeviláquA, o mais autêntico comentador do Código Civil porque autor do projeto vitorioso, "o sistema do Código é o seguinte: A lei é a forma por excelência do direito; num segundo plano e subsidiariamente, acha-se o costume;" o domínio da lei ilumina-se e dilata-se pela interpretação; se o trabalho mental do intérprete não consegue arrancar da letra nem do espírito da lei a norma jurídica aplicável ao caso, que tem diante de si, recorre ao processo da analogia; e quando este se mostra inadeqüado abre-se-lhe um espaço mais vasto, onde exercerá a sua livre investigação, à procura dos princípios gerais de direito", entre os quais inclui a eqüidade, como revela a seguinte passagem, logo depois: "As noções de liberdade, de justiça, de eqüidade, a moral, a sociologia e a legislação comparada concorrem para desprender do conjunto das idéias, que formam a base da civilização hodierna, os princípios gerais e as permanências do direito" (in Código Civil Comentado, 10. ${ }^{a}$ ed., 1953, v. I, p. 87/88).

A eqüidade, portanto, não é fonte de direito nem método de interpretação, mas noção muito mais ampla, que informa e orienta a atividade de pesquisa do direito.

Critérios de eqüidade, ou indicações orientadoras da atividade mental do intérprete, na sua procura da solução mais 
equânime, são fornecidos pelo art. $5 .^{\circ}$ da mesma Lei de Introdução: "Na aplicação da lei, o juiz atenderá aos fins sociais a que ela se dirige e às exigências do bem comum."

Para fazer justiça, ou seja, para decidir com eqüidade (e não por eqüidade), o juiz deverá se orientar pelos fundamentos teleológicos da lei: a busca do bem comum.

Comentando o texto do art. 5..$^{\circ}$, LIMONGI FrançA lembra que poderia ele ser considerado ocioso, "pois é evidente que as leis se destinam ao bem comum e só com este fito podem ser aplicadas por quem de direito. $O$ ordenamento, porém, não pode ter palavras supérfluas, de onde nos inclinarmos para o entendimento de que essa expressão se refere a um critério para a solução de casos duvidosos, em que, diante de dois ou mais caminhos viáveis, o intérprete deve seguir aquele que mais consulta à utilidade comum dos cidadãos e da República" (op. cit., p. 57).

3. Ao tratar de arbitragem, concede o Código Civil a mais ampla liberdade ao árbitro quando prevê, no art. 1.040, n. ${ }^{\circ}$ IV, que o compromisso poderá conter "a autorização, dada aos árbitros para julgarem por eqüidade, fora das regras e formas de direito."

A influência da escola da livre pesquisa do direito é evidente, o que se explica, na época, pelo fastígio daquela doutrina: O Código Civil vigora desde 1917. E óbvio, também, que a expressão "fora das regras e formas de direito" só pode ser entendida como regras e formas de direito positivo, como lembra LIMONGI FRANÇA, pois "seria um absurdo, contrário a todo o arcabouço do Código e do Sistema Jurídico Nacional, supor a possibilidade de juízo legítimo fora do direito, num sentido amplo" (grifos do original, in op. cit., p. 78).

Examinado à luz do contexto histórico, o sentido da norma em foco se revela, claramente: 0 árbitro não é um juiz, não está investido pelo Estado da função de dizer o Direito, e portanto não está constrangido a obedecer às regras e formas do direito positivo; diversamente, cabe-lhe compor interesses divergentes pautando sua decisão no que entender bom e equitativo ("de bono et aequo"), baseado naquele instinto de justiça natural superior ao justo legal, de que tratava ARISTóTELES. Incerto quanto às tendências da sociedade, desconfiando que o emaranhado de técnicas e elaborações doutrinárias pudessem vir a desviar o Direito de sua meta ideal de Justiça, prezando a liberdade individual e valorando a autonomia da vontade, o legislador do Código Civil resolveu devolver aos 
cidadãos, nesse caso, seu poder original de regular as pendências sem intervenção do Estado, de buscarem sua própria Justiça, de revelarem o Direito em sua forma mais pura e autêntica, através da decisão dos árbitros, manifestação da consciência jurídica do povo lastreada exclusivamente na noção intuitiva do justo: a eqüidade.

No art. 1.456, entretanto, o termo eqüidade é empregado com outro sentido. Reza esse dispositivo do Código Civil que "no aplicar a pena do art. 1.454," (perda do direito ao seguro) "procederá o juiz com eqüidade, atentando nas circunstâncias reais, e não em probabilidades infundadas, quanto à agravação dos riscos."

Já não se trata, agora, de liberação do árbitro das "regras e formas" do direito, mas de simples orientação interpretativa específica dada ao juiz. A menção às circunstâncias reais restringe o significado de "eqüidade", no texto do artigo: A recomendação é para que o juiz considere, com moderação, bom senso e equilíbrio, as probabilidades efetivas de agravamento dos danos. Indicação supérflua, se considerarmos que bom senso, equilíbrio e moderação são requisitos da interpretação de todos os contratos e de todas as leis, obrigação inerente à função do julgador.

4. Inspirado no art. 295 do projeto de CARNELUTTI que, com pequenas modificações de MoRTARA, veio a se transformar no art. 286 do Código de Processo Civil Italiano, dispunha o art. 114 do antigo Código de Processo Civil Brasileiro, refletindo as tendências da época do modelo: "Quando autorizado a decidir por eqüidade, o juiz aplicará a norma que estabeleceria se fosse legislador."

Essa disposição parece reproduzir, ao mesmo tempo, a última e a mais acentuada influência da escola da livre interpretação do direito, no sistema jurídico brasileiro, e mereceu a crítica de SPÍNOLA $F^{\circ}{ }^{\circ}$ : Não se deve entender que só quando autorizado por lei pode o intérprete julgar com eqüidade, pois seria absurdo que não o fizesse em todos os casos, sob pretexto de falta de autorização legal; esta apenas lhe confere maior liberdade de apreciar as circunstâncias e peculiaridades do caso concreto (op. cit., p. 248/250).

o Código de Processo Civil em vigor desde janeiro de 1974, superando aquela tendência, eliminou a menção à norma criada pelo juiz, dispondo simplesmente, no art. 127, que "o juiz só decidirá por eqüidade nos casos previstos em lei." 
Entenda-se, como decorre de toda a exposição anterior, que o artigo supra transcrito não veda, nem poderia fazê-lo, que o juiz decida com eqüidade, como é de seu dever; apenas restringe sua liberdade, proibindo-o de criar normas equitativas, em qualquer hipótese, e de interpretar o direito ao sabor de seu critério subjetivo de justiça, salvo expressa autorização legal.

Essa conclusão é reforçada pelo disposto nos arts. 1.075, n. ${ }^{0}$ IV, e 1.100, n. ${ }^{0}$ VI, do mesmo Código: O primeiro, repetindo a redação do art. $1.040, \mathrm{n}^{\circ} \mathrm{IV}$, do Código Civil, faculta, na instituição do juízo arbitral, conceder "autorização aos árbitros para julgarem por eqüidade, fora das regras e formas de direito"; e o segundo prevê a nulidade do laudo arbitral "se proferido por eqüidade, não havendo a autorização prevista" no primeiro desses artigos.

Raciocinando a contrário senso, o árbitro, quando autorizado pode decidir por eqüidade, desprezando regras e formas do direito positivo; o juiz, não. $\mathrm{Na}$ sentença, o juiz não tem liberdade para decidir por eqüidade, mas deve interpretar a norma de direito - escrita ou costumeira, ou ainda consubstanciada num dos princípios gerais de direito, mas sempre norma jurídica - interpretá-la, repetimos, segundo os ditames da lógica jurídica, e de acordo com a mais rigorosa técnica. Ocorre apenas que a eqüidade inspira o legislador, e o juiz deve sempre interpretar o direito com eqüidade, o que faz parte da boa técnica e é de irrefutável lógica.

Em suma: $\mathrm{O}$ árbitro pode decidir exclusivamente por eqüidade, e o juiz deve sempre julgar com eqüidade, em maior ou menor grau, conforme requeira o caso e indique o legislador, mas nunca poderá abandonar os critérios de interpretação para se valer exclusivamente da eqüidade.

\section{IV.}

Não tanto por ser um dos ramos mais novos do Direito, e muito mais porque é da sua própria natureza estar em contínua evolução; não tanto em razão de sua irrefreável tendência à universalização, e muito mais porque autogerado espontaneamente no seio da sociedade; não tanto por ser direito especial, e muito mais porque responde às necessidades vitais da imensa maioria dos homens, o Direito do Trabalho reflete, com muito maior rapidez e sensibilidade do que qualquer outro ramo do Direito, as alterações sociais, políticas e econômicas. 
1. As limitações naturais do Direito Internacional do Trabalho, entretanto, impedem que as Convenções e Recomendações emanadas da Organização Internacional do Trabalho acompanhem de perto essa rápida evolução: 0 processo de sua formação é lento, toma anos, e proposições muito avançadas não obteriam ratificações, transformando-se em utopias inatuantes, letra morta da lei.

Tampouco poderia a legislação estatal acompanhar o ritmo evolutivo do Direito do Trabalho, pelos mesmos motivos já apontados e por outros, entre os quais a própria resistência dos juristas, apegados à tendência conservadora do Direito, em geral.

Essa desatualização legislativa levou alguns doutrinadores, mais afoitos, a acreditar que as lacunas, no Direito do Trabalho, seriam mais freqüentes, e que o papel da eqüidade, no seu suprimento, muito maior.

$\mathrm{Na}$ realidade, as normas internacionais são muito genéricas, e cobrem, porisso mesmo, um vasto campo, ao estabelecerem princípios que irão informar as legislações nacionais dos países membros da OIT. Ora, tais princípios não se desatualizam com facilidade.

Além disso, a legislação trabalhista estabelece direitos básicos, mínimos, a serem completados e atualizados por normas de autoproteção que suprem as necessidades contingentes: As convenções coletivas, os acordos inter-sindicais e os regulamentos de empresa constituem as formas "sui generis", reconhecidas pela legislação estatal, para o preenchimento das lacunas do Direito do Trabalho.

Assim, a área trabalhista é ocupada, nos grandes espaços, pelos princípios gerais de Direito, em especial os do Direito do Trabalho, consubstanciados na doutrina e nas normas internacionais; e nos setores menores, pela autoproteção, através de regras de direito fixadas pelas próprias classes de empregados e patrões. Pouco terreno sobra para lacunas, que existem sim, porque inevitáveis, mas em número e extensão muito restritos, se comparadas com as que se verificam em outros ramos do Direito.

No suprimento dessas poucas lacunas, a eqüidade inspira o legislador estatal como postulado de Justiça, e norteia as partes, na autocomposição, como resultante de equilíbrio entre os interesses divergentes; mas não funciona como fonte de 
direito na atuação do intérprete, como expusemos (retro, sub II 1).

2. Alertado pelos prejuízos causados à produção, o Estado moderno abandonou sua posição de alheamento e passou a intervir na solução dos conflitos trabalhistas, inicialmente através do poder de polícia, depois constrangendo os litigantes à tentativa conciliatória e, por fim, criando órgãos especializados, que de provisórios passaram com o tempo a permanentes, no setor do Executivo, no Judiciário, ou em ambos.

Hoje, se as negociações espontâneas não chegam a bom termo e eclode um conflito coletivo, regra geral é um funcionário administrativo do Estado que intervém para, reunindo os representantes das classes em litígio, estudar uma solução que, alcançada, se transforma em convenção coletiva.

Na generalidade dos países latinos, há também uma Justiça Especializada em questões trabalhistas, cuja atividade primordial é a de solucionar os conflitos individuais. Inicialmente, a intervenção do órgão judiciário se faz no sentido de buscar a autocomposição da controvérsia, através da conciliação das partes; não obtendo êxito, passa então à fase jurisdicional, de heterocomposição.

Num e noutro caso, ao intervir como mediador, o órgão estatal, seja do setor executivo, seja do judiciário, exerce funções em tudo semelhantes as do árbitro. Ao orientar a solução o mediador, como o árbitro, age com inteira liberdade, desvinculado das regras e formas do direito positivo, baseado apenas no ideal de Justiça. Assim, considerando as circunstâncias e particularidades do caso concreto, o que é tido como justo pela "communis opinio" da época e local em que se encontra e o interesse geral da sociedade, representado pelo bem comum, o mediador oferece solução por eqüidade.

Essa forma especial de geração espontânea do direito, típica do Direito Coletivo do Trabalho, fornece à eqüidade o mais amplo campo de atuação no mundo jurídico moderno, como "fator constante e categórico na vida do Direito do Trabalho", na expressão de MozART V. RUssomano (op. e loc. cit.).

A atuação do mediador nos dissídios individuais do trabalho não é típica, vez que em outros tipos de litígio, notoriamente nos de Direito da Família, também ocorre intervenção com o intuito de obter a autocomposição das partes; nada obstante, apresenta características que a singularizam, senão vejamos. 
A tentativa conciliatória constitui, na generalidade das legislações nacionais, fase preliminar obrigatória de todos os dissídios trabalhistas, o que não ocorre senão esporadicamente em litígios de outra natureza. Além disso, a rápida e contínua evolução do Direito do Trabalho, assim como sua extrema sensibilidade às alterações políticas e econômicas da sociedade, já referidas no início deste item IV, exigem apurada percepção do mediador, ao detetar as tendências do comportamento social para fundamentar proposta de solução que atenda aos anseios de eqüidade, cuja noção corresponde à própria Justiça Social, no dizer de ARNALDo L. SUSSEKIND (op. e loc. cit.).

3. O fato de a legislação trabalhista estabelecer direitos mínimos, irredutíveis, acarreta a subversão da hierarquia normal das fontes, fenômeno característico estudado com proficiência por MáRIo DE LA CUEVA no seu monumental Derecho Mexicano del Trabajo.

Se a eqüidade, como vimos (retro, sub II 2), não é um método nem uma técnica, mas pressuposto lógico da interpretação, e o juiz não tem liberdade para aplicá-la como fundamento da decisão, julgando por eqüidade, tem entretanto obrigação precípua de ser justo, de decidir com eqüidade. Essa obrigação, comum a todos os juízes, é mais acentuada no caso do juiz trabalhista, exatamente porque tem maior liberdade do que os demais, na escolha do preceito legal que irá aplicar ao caso concreto. Várias são as fontes de direito a sua escolha, e face a ausência de hierarquização, deverá optar pela aplicação da que melhor atenda aos interesses do trabalhador, seguindo critério de eqüidade.

\section{V.}

1. A Consolidação das Leis do Trabalho emprega uma só vez o termo eqüidade, na Introdução, art. $8^{\circ}$ : "As autoridades administrativas e a Justiça do Trabalho, na falta de disposições legais ou contratuais, decidirão, conforme o caso, pela jurisprudência, por analogia, por eqüidade e outros princípios e normas gerais de direito, principalmente do direito do trabalho, e, ainda, de acordo com os usos e costumes, o direito comparado, mas sempre de maneira que nenhum interesse de classe ou particular prevaleça sobre o interesse público."

O texto, amálgama de outros, consolidados em 1943, apresenta defeitos notórios, a começar pelos da redação, em mau português; confunde métodos e técnicas de interpretação com 
fontes de integração do direito, e normas jurídicas (a menção a normas gerais não faz sentido, pois todas são necessariamente gerais) com princípios gerais de direito; não estabelece ordem preferencial dos métodos de interpretação que menciona, de mistura com as fontes etc. De aproveitável, resta a orientação teleológica da frase final, referente ao bem comum.

Quanto à eqüidade, o engano de estabelecê-la como fonte de integração do direito, herdado do Código de Processo Civil de 1939, é apenas parcial. Na verdade as autoridades administrativas, ao funcionarem como mediadores nas convençóes coletivas, têm liberdade para agir (embora não para decidir, como disposto no artigo) por eqüidade, e também é certo que os Tribunais do Trabalho, ao prolatarem sentenças normativas, decidem por eqüidade, como veremos; o próprio Juízo inferior, ao atuar como árbitro nas conciliações, vale-se da noção de eqüidade, como expusemos (retro, sub IV 2).

Nada obstante, a má redação pode confundir o intérprete, levando-o a concluir, erroneamente, que é livre para julgar dissídios individuais por eqüidade, com abstração dos métodos e técnicas interpretativas.

A utilização da boa técnica, aliás, torna ociosa a menção à eqüidade, pois as lacunas da lei não preenchidas por convenções coletivas, contratos individuais, regulamentos ou usos e costumes, são supridas pela aplicação analógica de outras normas, encontram precedentes jurisprudenciais ou, em última hipótese, são cobertas pelos princípios gerais de direito.

Se é válida a argumentação baseada na experiência pessoal, acrescentemos que durante mais de dezessete anos como Juiz do Trabalho no maior centro industrial da América Latina (São Paulo), jamais sentimos necessidade de fundamentar decisão de dissídio individual na noção de eqüidade e, o que nos parece mais significativo, nunca soubemos de sequer um caso autêntico de decisão por eqüidade, entre os julgados por quase uma centena de colegas, Juízes do Trabalho.

2. No Brasil, a atividade sindical é ainda incipiente, e as convenções coletivas espontâneas são raras. Os dissídios coletivos são submetidos a uma tentativa conciliatória prévia, perante autoridade administrativa do Ministério do Trabalho. Nessa fase, alcança-se número apreciável de auto-composições, através de convenções ou acordos coletivos.

Diante de resultado infrutífero nessa primeira fase administrativa, atribuiu o legislador aos Tribunais Trabalhistas a 
missão de tentar conciliar os litigantes e, não obtendo sua anuência, julgar os dissídios coletivos.

A decisão proferida nesses casos toma o nome de sentença normativa, porque estabelece normas gerais, aplicáveis às categorias profissional (dos empregados) e econômica (dos empregadores) em litígio, criando direitos exigíveis através de ações individuais.

A natureza jurídica das sentenças normativas tem sido muito debatida na doutrina, mas parece inquestionável que constituem normas jurídicas emanadas do Poder Judiciário, pois "a sentença normativa da Justiça do Trabalho estabelece uma regra geral, abstrata e impessoal. É um ato-regra, e, portanto, fonte de direito. Materialmente, é lei, embora tenha a forma de sentença", na síntese de DÉLIo MARANHÃo (op. cit., p. 179).

A lei n. ${ }^{\circ}$ 5.451, de 12 de junho de 1968, veio restringir drasticamente o poder normativo da Justiça do Trabalho brasileira, ao estabelecer critérios matemáticos rígidos, destinados a regular os cálculos dos reajustamentos salariais, com o objetivo de enquadrá-los na orientação da política econômica do governo. A liberdade de decisão dos Tribunais Trabalhistas tornou-se residual, limitada a um mínimo referente apenas, na prática, ao arredondamento do índice matemático encontrado, nos casos, que constituem a maioria, de estabelecimento de novos níveis salariais da categoria profissional.

No que diz respeito a outras condições de trabalho, porém, o poder normativo não sofreu restrições. Ao julgar essas questões, os Tribunais não aplicam ao caso concreto regras de direito preexistentes, mas compõem divergências criando novas normas aplicáveis às categorias em litígio. Nesse campo, decidem com inteira liberdade, orientados somente pela noção de eqüidade, objetivo ideal de todos os legisladores, no intuito de obter a justa composição dos interesses divergentes.

Considerando essa atividade criadora, a maior dose de liberdade de que goza na aplicação do direito, bem como a independência com que exerce as funções de mediador, nas conciliações, entende-se por que a Justiça do Trabalho é considerada jurisdição de eqüidade, em comparação com a Justiça Comum.

Nem por isso se há de concluir que o Juiz do Trabalho pode deixar de aplicar a lei por considerá-la injusta. A adver- 
tência é de DÉLIo Maranhão: A eqüidade... "deve ser manejada por mãos de artista, por juristas que conheçam o direito tout court, e não por aqueles que o ignorem e tentem suprir suas próprias deficiências por uma eqüidade que não é, em realidade, senão uma concepção primária" (op. cit., p. 185/186).

\section{Conclusões.}

1. Eqüidade significa justiça perfeita, meta ideal do legislador, na elaboração da norma jurídica, e do juiz, na aplicação do direito.

2. A eqüidade não é fonte formal ou material, nem fórmula de integração do direito, mas sim um postulado: o princípio axiomático de que todo o Direito tende a alcançar o ideal de Justiça.

3. A eqüidade não é um método nem uma técnica de interpretação, mas um pressuposto lógico da atividade interpretativa.

4. O árbitro pode decidir exclusivamente por eqüidade, e o juiz deve sempre julgar com eqüidade, mas este nunca poderá abandonar os métodos e técnicas de interpretação para fundamentar decisão exclusivamente no seu critério subjetivo de eqüidade.

5. No Direito do Trabalho, a eqüidade exerce as relevantes funções de:

a) inspirar o legislador;

b) nortear os responsáveis pela solução dos dissídios coletivos;

c) orientar os mediadores nas conciliações de litígios individuais e coletivos;

d) orientar o juiz na escolha do direito aplicável aos casos concretos. 